\title{
Pattern of hepatitis $B$ and $C$ infection among gravid women and their newborns in a tertiary care infirmary in India
}

\author{
Sheeba Marwah ${ }^{1}$, Ritin Mohindra ${ }^{2}$, Sushmita Sharma $^{3}$, Praveen V. Mohan ${ }^{4}$ \\ ${ }^{1}$ Department of Obstetrics \& Gynecology, ${ }^{2}$ Department of Internal Medicine, VMMC and Safdarjung Hospital, New \\ Delhi, India \\ ${ }^{3}$ Department of Obstetrics \& Gynecology, Gian Sagar Medical College \& hospital, Patiala, Punjab, India \\ ${ }^{4}$ Department of Obstetrics and Gynecology, Institute of Medical Sciences, Mullana, Ambala, India
}

Received: 21 November 2015

Revised: 25 November 2015

Accepted: 08 January 2016

\section{*Correspondence:}

Dr. Sheeba Marwah,

E-mail: sheebamarwah@yahoo.co.in

Copyright: $\odot$ the author(s), publisher and licensee Medip Academy. This is an open-access article distributed under the terms of the Creative Commons Attribution Non-Commercial License, which permits unrestricted non-commercial use, distribution, and reproduction in any medium, provided the original work is properly cited.

\section{ABSTRACT}

Background: The objective is to determine the prevalence of the hepatitis $\mathrm{B}$ and $\mathrm{C}$ virus among pregnant women, to assess impact of maternal hepatitis B virus (HBV) or hepatitis C virus (HCV) carrier status on pregnancy outcomes and to gauge the risk factors associated with them. Antenatal clinic attenders and women undergoing termination of pregnancy over three years.

Methods: The study was conducted in Gian Sagar Medical College \& Hospital, Patiala, Punjab, India. Hepatitis B antigen and Hepatitis $\mathrm{C}$ virus antibody testing of sera from specimens sent to the hospital laboratory for routine serological testing. The results were then linked to risk information, obstetric complications and pregnancy outcome.

Results: Overall HBsAg and anti-hepatitis C antibody prevalence was 1.2\% (33/2031). Increased risk of transmission was associated with sexually transmitted diseases and previous surgical procedures. High rates of preterm labor pains, CD (27.27\%), and non-reassuring fetal heart rate patterns and meconium stained liquor were found in the seropositive patients.

Conclusions: Maternal hepatitis B and C carrier status is an eminent risk factor for adverse pregnancy outcome.

Keywords: Hepatitis, Hepatitis B antigen, Anti-hepatitis C antibody, Pregnancy outcomes, Sero-prevalance, Risk factors

\section{INTRODUCTION}

Approximately one-third of world's population has serological evidence of past or present infection with HBV. About 350 million people worldwide are chronic carriers with nearly $6,00,000$ dying of $\mathrm{CHB}$ complications (acute liver failure, cirrhosis and HCC annually. ${ }^{1-3}$ The prevalence of HBsAg in gravid women alters with geographical location and ethnicity, being $6 \%$ in Asian women, $1 \%$ in African-Americans, $0.6 \%$ in nonHispanic whites and $0.1 \%$ in Hispanics. In endemic areas such as China and South East Asia, it may be as high as $10-20 \% .^{4}$ The same in India is intermediate, with a population prevalence of $4 \%$ and an estimated $1,40,000$ carriers.

Likewise, prevalence of HCV infection is approximately 2.2-3.0\% globally, with highest in African and Eastern Mediterranean region. ${ }^{5,6}$ The incidence of $\mathrm{HCV}$ during pregnancy is $1 \%-2.4 \%$. $^{7}$ Of infants born to seropositive women, 6 in 100 will acquire $\mathrm{HCV}$ perinatally, translating into almost 2500 perinatally acquired infections annually. ${ }^{7}$ Most persons acutely infected with HCV develop a persistent infection and nearly 70\% experience chronic necro-inflammation of liver. 
HBV is transmitted from infected mothers to infants via trans placental transmission, during parturition or postnatally through breast milk. Perinatal transmission appears to be the most important factor in determining the primacy in India. Before $\mathrm{HBV}$ vaccine was integrated into routine immunization program, proportion of babies becoming HBV carriers was roughly $10-30 \%$ for mothers who were $\mathrm{HBsAg}$ positive but $\mathrm{HBeAg}$ negative, increasing to $70-90 \%$ when mother was also $\mathrm{HBeAg}$ positive. ${ }^{8-10}$ The majority of perinatally acquired infection $(>95 \%)$ results in CHB infection, due to induction of an immune tolerant state of variable duration. Therefore, prevention of perinatal transmission remains an imperative target in the struggle for global eradication of HBV infection.

$\mathrm{HCV}$ is transmitted through parenteral exposure, especially blood transfusions and the use of injectable drugs. The vertical, sexual and intra familial transmission of HCV have also been established.

Most antenatal women are recognized to be $\mathrm{HBV} / \mathrm{HCV}$ carriers by their physicians from the commencement of their pregnancies. Viral hepatitis during pregnancy is associated with a high risk of maternal complications, high rate of vertical transmission (causing fetal and neonatal hepatitis) and is a leading cause of maternal mortality. ${ }^{11}$ Epidemiological data on $\mathrm{HBV} / \mathrm{HCV}$ infection is hence vital for obstetricians for optimal management of parturients and also program managers and health planners, to determine its morbidity and mortality, effect on parturition and transmission of infection to the newborn, to formulate preventive strategies. Though several studies on epidemiology of viral hepatitis in pregnancy are available from Africa, there is paucity of such up to date data among obstetric literature in India, especially regarding the potential adverse pregnancy outcomes related to maternal $\mathrm{HBV} / \mathrm{HCV}$ carrier status.

The aim of this extant population-based study was thus to examine the sero-prevalence of HBsAg and HCV among pregnant women, possible risk factors for perinatal transmission of $\mathrm{HBV} / \mathrm{HCV}$ infection and the impact of maternal $\mathrm{HBV} / \mathrm{HCV}$ carrier status on pregnancy outcomes in a tertiary care hospital.

\section{METHODS}

The study was carried out at Gian Sagar Medical College \& Hospital over a span of three years from April 2011 to June 2014. Women in any trimester of pregnancy, with or without jaundice, attending the daily antenatal clinic or emergency of the hospital were included. After informed consent, detailed history was taken and complete clinical examination was performed. Also $4 \mathrm{ml}$ blood was collected and the sera obtained were tested for HBsAg and anti-HCV in laboratory using ELISA (Span Diagnostic Ltd, Surat, India). For the purpose of this study, we defined positive HBV status as having a reactive $\mathrm{HBsAg}$; and a positive $\mathrm{HCV}$ status as having a reactive anti-HCV result.

Women who tested positive for either of two underwent appropriate counseling and treatment, if warranted, and were then further evaluated for the virological characteristics of the hepatitis virus (HBsAg positive or negative, $\mathrm{HBe}$ antigen positive or negative and antiHCV), co-infection with HIV. Socio-demographic profile, reproductive, medical and surgical history, as well as history pertaining to $\mathrm{HBV} / \mathrm{HCV}$ infection and high-risk behaviors was extracted in detail from them. At the time of admission for delivery, history was reviewed along-with a thorough examination to note significant obstetric complications if occurred.

Additionally, woman's labor and delivery details, postpartum complications and neonatal outcomes were documented. Cord blood was collected at time of delivery and tested for HBsAg, HBeAg and HBV DNA; presence of HBV DNA in cord blood was taken as evidence of vertical transmission of HBV. The entire information was tabulated on a predesigned record proforma. An entire analysis was done using available Statistical Program for Social Sciences (SPSS 18 for Windows) after applying appropriate tests. $\mathrm{P}$ values $<0.05$ were considered as statistically significant.

\section{RESULTS}

\section{HBsAg/HCV seroprevalence rate}

Thirty three hepatitis seropositive pregnant women were identified out of 2031 deliveries (1.2\%) during the study period, amongst which 27 were HBV carriers (81.88\%) and 6 were $\mathrm{HCV}$ carriers. None of the women were coinfected with $\mathrm{HBV}$ and HCV. Since feto-maternal outcomes were comparable between $\mathrm{HBV}$ and $\mathrm{HCV}$ carriers with no significant differences observed, the two groups were combined for further analyses. One of the HBV carriers had a co-infection with HIV.

\section{Socio-demographic profile}

The mean age of seropositive patients was 23.8 years. The highest prevalence was perceived in the age group of 21-25 years (84.84\%). An increasing trend in the prevalence of seropositivtity was observed with higher parity, being $6(18.18 \%)$ in primigravida, $10 /(30.30 \%)$ in 2nd gravida and13 $(39.39 \%)$ in 3rd gravida women. The prevalence rates in the first three parity groups were significantly different $(\mathrm{p}<0.05)$ (Table 1$)$.

The mean BMI of all these women, mostly Sikh and Hindu by religion, was $21.93+2.025 \mathrm{~kg} / \mathrm{m}^{2}$. Majority of subjects hailed from rural background (87.88\%) and belonged to low $(69.70 \%)$ and middle $(30.30 \%)$ socioeconomic status. A further breakup of socio demographic data revealed highest $\mathrm{HBsAg} / \mathrm{anti}-\mathrm{HCV}$ antibody positivity in illiterates. Nearly all were 
housewives $(96.96 \%)$ without any prior regular antenatal care. All these observations substantiated the section of society which attends the institute for its medical problems.

Table 1: Socio demographic Characteristics of $\mathbf{3 3}$ seropositive women for HBsAg/ anti-HCV antibody.

\begin{tabular}{|c|c|c|}
\hline Characteristic & $\begin{array}{l}\text { No. of } \\
\text { seropositive } \\
\text { women (n) }\end{array}$ & $\%$ \\
\hline \multicolumn{3}{|l|}{ Age,(years) } \\
\hline$<20$ & 0 & 0 \\
\hline $21-25$ & 28 & 84.84 \\
\hline $26-30$ & 4 & 12.12 \\
\hline $31-35$ & 1 & 3.03 \\
\hline \multicolumn{3}{|l|}{ Gravidity, no. } \\
\hline 1 & 6 & 18.18 \\
\hline 2 & 10 & 30.30 \\
\hline 3 & 13 & 39.39 \\
\hline$\geq 4$ & 4 & 12.12 \\
\hline \multicolumn{3}{|l|}{ Education } \\
\hline Illiterate & 25 & 75.75 \\
\hline Primary & 4 & 12.12 \\
\hline Middle & 1 & 3.03 \\
\hline High school & 2 & 6.06 \\
\hline Secondary & 1 & 3.03 \\
\hline $\begin{array}{l}\text { Graduation/ } \\
\text { Post graduation }\end{array}$ & 0 & 0 \\
\hline \multicolumn{3}{|l|}{ Religion } \\
\hline Hindu & 15 & 45.45 \\
\hline Sikh & 16 & 48.48 \\
\hline Muslim & 2 & 6.06 \\
\hline Christian & 0 & 0 \\
\hline Others & 0 & 0 \\
\hline \multicolumn{3}{|l|}{ Address } \\
\hline Urban & 4 & 12.12 \\
\hline Rural & 29 & 87.88 \\
\hline \multicolumn{3}{|c|}{ Socioeconomic status } \\
\hline $\mathrm{i}$ & 0 & 0 \\
\hline ii & 0 & 0 \\
\hline iii & 10 & 30.30 \\
\hline iv & 20 & 60.60 \\
\hline $\mathrm{v}$ & 3 & 9.09 \\
\hline \multicolumn{3}{|l|}{ Occupation } \\
\hline Housewife & 32 & 96.96 \\
\hline Working & 1 & 3.03 \\
\hline \multicolumn{3}{|l|}{ Antenatal care } \\
\hline Booked & 2 & 6.06 \\
\hline Unbooked & 31 & 93.93 \\
\hline \multicolumn{3}{|l|}{ BMI } \\
\hline$<18.9$ & 5 & 15.15 \\
\hline $19-24.9$ & 22 & 66.67 \\
\hline $25-29.9$ & 4 & 12.12 \\
\hline $30-34.9$ & 2 & 6.06 \\
\hline $35-39.9$ & 0 & 0 \\
\hline$>40$ & 0 & 0 \\
\hline
\end{tabular}

\section{Medical and obstetric complications}

Of the 33 seropositive gravid women, only three had acute hepatitis B while remaining were asymptomatic. Fortunately, the former did not seem to transmit infection to her baby. Common complications observed were preterm labour (18.18\%), oligohydramnios (15\%), and hypertensive disorders in pregnancy $(12.12 \%)$ (Table 2$)$.

Table 2: Medical and obstetric complications.

\begin{tabular}{|c|c|c|}
\hline Complications & $\begin{array}{l}\text { No. of } \\
\text { seropositive } \\
\text { women(n) }\end{array}$ & $\%$ \\
\hline Deranged LFTs & 3 & 9.09 \\
\hline Preterm delivery & 3 & 9.09 \\
\hline HDP & 4 & 12.12 \\
\hline IUGR & 2 & 6.06 \\
\hline Oligohydramnios & 5 & 15.15 \\
\hline PROM & 6 & 18.18 \\
\hline Pulmonary embolism & 0 & 0 \\
\hline Cholestasis & 3 & 9.09 \\
\hline Coagulopathy & 1 & 3.03 \\
\hline Placenta previa & 1 & 3.03 \\
\hline Placental abruption & 0 & 0 \\
\hline GDM & 2 & 6.06 \\
\hline PGDM & 1 & 3.03 \\
\hline polyhydraminos & 0 & 0 \\
\hline $\begin{array}{l}\text { Excessive wt gain } \\
(>11 \mathrm{Kg})\end{array}$ & 3 & 9.09 \\
\hline
\end{tabular}

\section{Risk factors for $\mathrm{HBV} / \mathrm{HCV}$ infection in $\mathrm{HBs} A \mathrm{~g}$ positive/ anti HCV women}

In all at least one of these significant risk factors was present in $24(72.72 \%)$ seropositive women.

Early age at marriage was present in $84.84 \%$ of seropositive parturients. One sero-positive women had history of tattooing, whilst $30 \%$ gave history of previous surgical procedures (dilatation and curettage in 11 and $\mathrm{CD}$ in 7). Information on status of husband was available only for 20 women as husbands of remaining 13 seropositive women declined HBsAg/anti HCV testing. Three husbands were HBsAg positive, while none was anti HCV positive. Past history of sexually transmitted infections like Molluscum Contagiosum was found in one of the HCV positive pregnant woman. None of the females reported known sero positivity in their sibling(s). History of blood transfusion within last 3-5 years was present in $6 \%$ women. One woman was a health care worker and a smoker also (Table 3). 
Table 3: Prevalence of risk factors among 33 pregnant women seropositive for HBsAg /anti-HCV antibody.

\begin{tabular}{|c|c|c|}
\hline Risk factors & No.of seropositive women(n) & $\%$ \\
\hline \multicolumn{3}{|l|}{ Early age at marriage } \\
\hline No & 5 & 15.15 \\
\hline Yes & 28 & 84.84 \\
\hline \multicolumn{3}{|l|}{ Multiparity } \\
\hline No & 6 & 18.18 \\
\hline Yes & 27 & 81.81 \\
\hline \multicolumn{3}{|l|}{ Smoking } \\
\hline No & 32 & 96.96 \\
\hline Yes & 1 & 3.03 \\
\hline \multicolumn{3}{|l|}{ Substance abuse } \\
\hline No & 32 & 96.96 \\
\hline Yes & 1 & 3.03 \\
\hline \multicolumn{3}{|c|}{ Multiple sexual partners } \\
\hline No & 33 & 100 \\
\hline Yes & 0 & 0 \\
\hline \multicolumn{3}{|l|}{ Fertility treatment } \\
\hline No & 28 & 84.84 \\
\hline Yes & 5 & 15.15 \\
\hline \multicolumn{3}{|c|}{ Previous Surgical procedures } \\
\hline No & 15 & 45.45 \\
\hline Yes & 18 & 54.54 \\
\hline Dilatation \& curettage & 11 & 33.33 \\
\hline $\begin{array}{l}\text { Caesarean } \\
\text { delivery }\end{array}$ & 7 & 21.21 \\
\hline \multicolumn{3}{|c|}{ Acupuncture and/or tattooing } \\
\hline No & 32 & 96.96 \\
\hline Yes & 1 & 3.03 \\
\hline \multicolumn{3}{|l|}{ Circumcision } \\
\hline No & 32 & 96.96 \\
\hline Yes & 1 & 3.03 \\
\hline \multicolumn{3}{|c|}{ Positive status of partner } \\
\hline No & 30 & 90.90 \\
\hline Yes & 3 & 9.09 \\
\hline \multicolumn{3}{|l|}{ History of jaundice } \\
\hline No & 31 & 93.93 \\
\hline Yes & 2 & 6.06 \\
\hline \multicolumn{3}{|c|}{ Previous blood transfusion } \\
\hline No & 31 & 93.93 \\
\hline Yes & 2 & 6.06 \\
\hline \multicolumn{3}{|l|}{ HIV positive status } \\
\hline No & 32 & 96.96 \\
\hline Yes & 1 & 3.03 \\
\hline \multicolumn{3}{|l|}{ History of RTI/STD } \\
\hline No & 31 & 93.93 \\
\hline Yes & 2 & 6.06 \\
\hline \multicolumn{3}{|c|}{ History of having received parentral drugs from untrained personnel } \\
\hline No & 27 & 81.81 \\
\hline Yes & 6 & 18.18 \\
\hline \multicolumn{3}{|c|}{ Family history of seropositivity } \\
\hline No & 32 & 96.96 \\
\hline Yes & 1 & 3.03 \\
\hline \multicolumn{3}{|l|}{ Use of OCPs } \\
\hline No & 30 & 90.90 \\
\hline Yes & 3 & 9.09 \\
\hline
\end{tabular}


Table 4: Pregnancy outcomes in seropositive women forHBsAg /anti-HCV antibodies.

\begin{tabular}{|c|c|c|}
\hline $\begin{array}{l}\text { Outcome in } \\
\text { seropositive group }\end{array}$ & $\begin{array}{l}\text { No. of } \\
\text { women }\end{array}$ & $\%$ \\
\hline \multicolumn{3}{|l|}{$\begin{array}{l}\text { Pregnancy duration, } \\
\text { wk }\end{array}$} \\
\hline$<37$ & 3 & 9.09 \\
\hline $37-41$ & 29 & 87.87 \\
\hline$>4101$ & 1 & 3.03 \\
\hline \multicolumn{3}{|l|}{ Onset of labor } \\
\hline Spontaneous & 24 & 72.72 \\
\hline Induced & 7 & 21.21 \\
\hline \multicolumn{3}{|l|}{ Fetal bradycardia } \\
\hline Yes & 5 & 15.15 \\
\hline No & 28 & 84.84 \\
\hline \multicolumn{3}{|l|}{$\begin{array}{l}\text { Meconium-stained } \\
\text { liquor }\end{array}$} \\
\hline Yes & 9 & 27.27 \\
\hline No & 24 & 72.72 \\
\hline \multicolumn{3}{|l|}{ Mode of delivery } \\
\hline Vaginal & 24 & 72.72 \\
\hline LSCS & 9 & 27.27 \\
\hline \multicolumn{3}{|l|}{ Outcome } \\
\hline Live born & 31 & 93.93 \\
\hline Still born & 2 & 6.06 \\
\hline \multicolumn{3}{|l|}{ Birth weight, g } \\
\hline$<2500$ & 8 & 24.24 \\
\hline$>2500$ & 25 & 75.75 \\
\hline \multicolumn{3}{|c|}{ Apgar score at $1 \mathrm{~min}$} \\
\hline $\operatorname{Low}(<7)$ & 8 & 24.24 \\
\hline $\operatorname{High}(>7)$ & 25 & 75.75 \\
\hline \multicolumn{3}{|l|}{ Sex of newborn } \\
\hline Male & 16 & 48.48 \\
\hline Female & 17 & 51.51 \\
\hline \multicolumn{3}{|l|}{ Size of newborn } \\
\hline SFD & 3 & 9.09 \\
\hline AFD & 30 & 90.90 \\
\hline \multicolumn{3}{|c|}{$\begin{array}{l}\text { Neonatal resuscitation } \\
\text { required }\end{array}$} \\
\hline No & 29 & 87.87 \\
\hline Yes & 2 & 6.06 \\
\hline \multicolumn{3}{|l|}{ Admission to NICU } \\
\hline No & 0 & 0 \\
\hline Yes & 31 & 93.93 \\
\hline \multicolumn{3}{|l|}{ Any gross $\mathrm{CMF}$} \\
\hline No & 32 & 96.96 \\
\hline Yes & 1 & 3.03 \\
\hline \multicolumn{3}{|l|}{$\begin{array}{l}\text { Neonatal jaundice } \\
\text { (Pathological) }\end{array}$} \\
\hline No & 31 & 93.93 \\
\hline Yes & 0 & 0 \\
\hline \multicolumn{3}{|l|}{ Perinatal mortality } \\
\hline No & 31 & 93.93 \\
\hline Yes & 0 & 0 \\
\hline
\end{tabular}

\section{Pregnancy outcomes (Table 4)}

High rates of $\mathrm{CD}(27.27 \%)$, and non-reassuring fetal heart rate patterns and meconium stained liquor were found in the seropositive patients. Among the 9 women who had $\mathrm{CD}, 7$ were performed in emergency while elective $\mathrm{CD}$ were done for malpresentation and placenta previa. 31 babies were delivered alive among which 14 (45.2\%) showed evidence of vertical transmission. $24.4 \%$ babies were low birth weight and $24.4 \%$ had low Apgar scores, with 2 of them requiring NICU care. One of the still born babies had anencephaly. None of the babies developed jaundice postnatally.

\section{DISCUSSION}

This is one of the largest studies demonstrating the prevalence of $\mathrm{HBsAg} / \mathrm{anti-HCV}$ antibodies in symptomatic pregnant women from India. The HBsAg/anti HCV antibody sero-prevalence rate of $1.2 \%$ in this study indicates intermediate endemicity of $\mathrm{HBV} / \mathrm{HCV}$ infection in the region. Sero-epidemiological studies of different populations show variations and differences (Table 5). This difference may be because of the type of population studied, different geographical regions, genetic and socioeconomic factors.

Table 5: Comparison of seroprevalence rates of HBsAg/ anti HCV among pregnant women in different populations.

\begin{tabular}{|lll|l|}
\hline $\begin{array}{l}\text { Author, } \\
\text { year and } \\
\text { references }\end{array}$ & $\begin{array}{l}\text { Population } \\
\text { studied }\end{array}$ & $\begin{array}{l}\text { Number } \\
\text { of persons } \\
\text { screened }\end{array}$ & $\begin{array}{c}\text { HBsAg } \\
\text { and /or } \\
\text { anti HCV } \\
\text { +ve (\%) }\end{array}$ \\
\hline $\begin{array}{l}\text { Murad et } \\
\text { al.2013 }\end{array}$ & Yemen & 400 & $10.8 \%$ \\
\hline $\begin{array}{l}\text { Makuwa et } \\
\text { al. 2008 }\end{array}$ & Gabon & 1,186 & 9.20 \\
\hline $\begin{array}{l}\text { Kabiru et al. } \\
2010^{1}\end{array}$ & Nigeria & 1,052 & $6.08 \%$ \\
\hline $\begin{array}{l}\text { Zahran et al. } \\
2010^{19}\end{array}$ & Egypt & 500 & 6.4 and $4 \%$ \\
\hline $\begin{array}{l}\text { Rasha M } \\
\text { Elsheikh et } \\
\text { al. 2007 }\end{array}$ & Sudan & 728 & $5.6 \%$ \\
\hline $\begin{array}{l}\text { Mohammed } \\
\text { et al. 2008 }\end{array}$ & $\begin{array}{l}\text { Saudi } \\
\text { Arabia }\end{array}$ & & 1.60 \\
\hline $\begin{array}{l}\text { Bertolini et } \\
\text { al. 2006 }\end{array}$ & Brazil & 3,188 & $1.5 \%$ \\
\hline $\begin{array}{l}\text { Present } \\
\text { Study 2014 }\end{array}$ & Punjab,India & 2031 & $1.2 \%$ \\
\hline $\begin{array}{l}\text { Dwivedi et } \\
\text { al2008 }\end{array}$ & $\begin{array}{l}\text { Allahabad, } \\
\text { India }\end{array}$ & 4,000 & $0.9 \%$ \\
\hline $\begin{array}{l}\text { A kumar et } \\
\text { al 2004 }\end{array}$ & $\begin{array}{l}\text { New Delhi, } \\
\text { India }\end{array}$ & 1900 & $0.73 \%$ \\
\hline $\begin{array}{l}\text { Ari Safir } \\
2009^{17}\end{array}$ & Sudan & 186619 & $0.4 \%$ \\
\hline
\end{tabular}


A finding similar to that by Elsheikh et al and Murad et al in this study is that none of the patients were infected by both $\mathrm{HBV}$ and $\mathrm{HCV} .^{11,12}$

We noted high seropositivity in women between 21-25 age group in multiparous women. This was akin to the observations made by previous researchers. ${ }^{13}$ The majority of the mothers were from low socioeconomic backgrounds suggesting that the infection was more prevalent in those with a lower educational level. ${ }^{11-13}$

The absolute number of only 33 positive cases precludes the detection of small differences in the prevalence of risk factors; however, the prevalence of HBsAg/anti$\mathrm{HCV}$ antibodies have been reported to increase with age and to be the highest among women older than 40 years. The findings that $84.4 \%$ of the positive women had at least one significant risk factor clearly demonstrates that high risk screening of pregnant women is not a sensitive method, and that as many as a quarter of seropositive women may be lost by such practice. This justifies routine screening of all antenatal women in India for HBsAg and anti HCV antibody.

A much higher sexual transmission has been long recognized as a major source of HBV transmission in all areas of the world. ${ }^{14,15}$ It is therefore not astounding that early age at sexual debut and previous history of STIs were the significant risk factors for seropositivity in this study. However multiple sexual partners were not identified as a risk factor in our subjects owing to social inhibitions. Also, the current program of hepatitis B vaccination in infancy and children in India offers a longterm solution to HBV infection, but its impact on seroprevalence rates would take some time to establish. However, none of the known risk factors such as history of contact with jaundiced patient, tattooing, history of dental manipulation, circumcision in the extant study were found to be significantly associated with the HCV infection among gravid women. ${ }^{11,15,16}$ Also there is a slightly increased risk of seropositivity in individuals with a history of dilation and curettage or previous LSCS, insinuating a blood-borne mode of transmission. Unsterilized medical equipment is likely to be an important risk factor in these patients.

Drug abuse is known to be strongly associated with poor neonatal outcomes. Our population differ significantly from other studies investigating the outcome of patients with hepatitis, as smoking and substance abuse is extremely rare $(3.03 \%)$. High rates of low birth weight, preterm deliveries and low Apgar scores $(<7)$ at $1 \mathrm{~min}$ were noted. These were in concordance with studies published among other populations till date. ${ }^{15-17}$ An exception is the prevalence of gestational diabetes mellitus among hepatitis carriers, which was found to be higher only in women who had an excessive weight gain during their pregnancy. The differences in BMI values may explain the diversity of the results. Literature has related the adverse pregnancy outcomes to a chronic inflammatory state in which increased serum concentrations of pro-inflammatory cytokines play an important role in premature labor and PROM.

Our study has few limitations. The population investigated consisted only of women able to access antenatal care, and the prevalence reported here may have underestimated the true prevalence among pregnant women in the community. Secondly, because of the test being expensive, only 6 seropositive parturients agreed to be further investigated for virological characteristics. Therefore, we were unable to show any significant correlation between higher viral loads at the time of pregnancy and adverse outcomes. Also, many patients did not have a follow-up regarding their liver disease during their pregnancies. Further prospective studies should focus on these critical factors, including careful observation and preconception consultation. Nevertheless, we agree with the management suggested by Jonas for hepatitis carriers during pregnancy, including recognition of maternal virological status and assessment of liver disease. We recommend the referral of those patients to high-risk pregnancy clinics with careful observation during pregnancy and delivery.

\section{CONCLUSIONS}

Maternal HBV or HCV carrier status is an independent risk factor for adverse perinatal outcome, and careful surveillance as high-risk pregnancy is warranted.

\section{ACKNOWLEDGEMENTS}

We cannot repay in words, and in deed, love and thanks to all our patients suffering from Hepatitis B/ C for their contribution towards making this review reach a successful culmination. We hereby pay our sublime observance and cordial thanks to all of them besides wishing them a speedy recovery.

Funding: No funding sources

Conflict of interest: None declared

Ethical approval: The study was approved by the Institutional Ethics Committee

\section{REFERENCES}

1. Rabiu KA, Akinola OI, Adewunmi AA, Omololu OM, Ojo TO. Risk factors for hepatitis B virus infection among pregnant women in Lagos, Nigeria. Acta Obstetricia et Gynecologica. 2010; 89:1024-28.

2. World Health Organization. Hepatitis B. Fact sheet no. 204; July 2012. http://www.who.int/mediacentre/factsheets/fs2. Accessed on 3 November 2015.

3. Cheung KW, Seto MTY, Wong SF. Towards complete eradication of hepatitis $\mathrm{B}$ infection from perinatal transmission: review of the mechanisms of in utero infection and the use of antiviral treatment 
during pregnancy. European J Obstet Gynecol Reprod Biol. 2013;169:17-23.

4. Hou J, Liu Z, Gu F. Epidemiology and prevention of hepatitis B virus infection. Int J Med Sci. 2005;2:50 7.

5. Global surveillance and control of hepatitis C. Report of a WHO Consultation organized in collaboration with the Viral Hepatitis Prevention Board, Antwerp, Belgium. J Viral Hepat. 1999;6:35-47.

6. Alter MJ, Kruszon-Moran D, Nainan OVMcQuillan GM, Gao F, Moyer LA et al. The prevalence of hepatitis C virus infection in the United States, 1988 through 1994. N England J Med. 1999;341:556-62.

7. Martha W.F. Rac, Jeanne S. Sheffield. Prevention and management of viral hepatitis in pregnancy. Obstet Gynecol Clin N Am. 2014;41:573-92.

8. Lok AS. Chronic hepatitis B. N Engl J Med. 2002;346:1682-3.

9. Steven CE, Neurath RA, Beasley P, Szmuness W. $\mathrm{HBeAg}$ and anti-HBe detection by radioimmunoassay-correlation with vertical transmission of HBV in Taiwan. J Med Virol. 1979;3:237-41.

10. Wonke B, Hoffbrand AV, Brown D, Dusheiko G. Antibody to hepatitis B virus in multiply transfused patients with thalassaemia major. J Clin Path. 1990;43:638-40.

11. Murad EA, Babiker SM, Gasim GI, Rayis DA, Adam I. Epidemiology of hepatitis B and hepatitis C virus infections in pregnant women in Yemen. BMC Preg Childbirth. 2013;13:127.

12. Elsheikh RM, Daak AA, Elsheikh MA, Karsany MS, Adam I: Hepatitis B virus and hepatitis C virus in pregnant Sudanese women. Virol J. 2007;4:104.

13. Dwivedi M, Misra SP, Misra V, Pandey A, Pant S, Singh R et al. Seroprevalence of hepatitis B infection during pregnancy and risk of perinatal transmission. Indian J Gastroenterol. 2011;30(2):66-71.

14. Ndjomou J, Kupfer B, Kochan B, Zekeng L, Kaptue L, Matz B. Hepatitis C virus infection and genotypes among human immunodeficiency virus high risk groups in Cameroon. J Med Virol. 2002;66:179-86.
15. Kumara A, Sharma KA, Gupta RK, Karb P, Murthy NS. Hepatitis $C$ virus infection during pregnancy in North India. Intern J Gynecol Obstet. 2005;88:55-6.

16. Altinbas S, Erdogan M, Danişman N. The seroprevalences of $\mathrm{HBs} \mathrm{Ag}$ and anti-HCV in pregnant women in Ankara. Arch Gynecol Obstet. 2010;281:371.

17. Safir A, Levy A, Sikuler E, Sheiner E. Maternal hepatitis B virus or hepatitis C virus carrier status as an independent risk factor for adverse perinatal outcome. Liver Intern. 2010;2010:765-80.

18. Makuwa $M$, Caron $M$, Souquière $S$, MalongaMouelet G, Mahé A, Kazanji M. Prevalence and genetic diversity of hepatitis $\mathrm{B}$ and delta viruses in pregnant women in Gabon: molecular evidence that hepatitis delta virus clade 8 originates from and is endemic in central Africa. J Clin Microbiol. 2008;46:754-6.

19. Zahran KM, Badary MS, Agban MN, Nafesa HR, Aziz A. Pattern of hepatitis virus infection among pregnant women and their newborns at the Women's Health Center of Assiut University, Upper Egypt. Intern J Gynecol Obstet. 2010;111:171-4.

20. Alrowaily MA, Abolfotouh MA, Ferwanah MS. Hepatitis B virus sero-prevalence among pregnant females in Saudi Arabia. Saudi J Gastroenterol. 2008;14:70-2.

21. Bertolini DA, Pinho JRR, Saraceni CP, Moreira RC, Granato CFH, Carrilho FJ. Prevalence of serological markers of hepatitis B virus in pregnant women from Paraná State, Brazil. Braz J Med Biol Res. 2006;39:1083-90.

Cite this article as: Marwah S, Mohindra R, Sharma S, Mohan PV. Pattern of hepatitis B and C infection among gravid women and their newborns in a tertiary care infirmary in India. Int $\mathbf{J}$ Reprod Contracept Obstet Gynecol 2016;5:354-60. 